\title{
Controlling Mathematics Anxiety by the Views of Guidance and Psychological Counseling Candidates
}

\author{
Davut Aydın * \\ Ahi Evran University, TURKEY
}

\author{
Cahit Aytekin \\ Ahi Evran University, TURKEY
}

Received: December 16, 2018 - Revised: January 12, 2019 - Accepted: February 5, 2019

\begin{abstract}
The aim of this study is to reveal the suggestions of guidance and psychological counseling candidates (GPC) in dealing with math anxiety. The study analysed 50 GPC candidates' opinions and suggestions on math anxiety. The research study utilized case study method. The participants were asked to respond what kind of studies they would suggest to their clienst in order to overcome math anxiety once they begin to work in their profession. The interviews transcripts were converted into written documents. Content analysis was made on those documents to find GPC candidates' suggestions and opinions. Based on the findings, it can be concluded that the reasons of math anxiety can vary from individual to individual. Therefore, it was emphasized that the studies to determine the causes of math anxiety should be specific for each individual. Then, consultancy service should be formed based on the assessment of reasons that cause anxiety for each person. If the individual's math anxiety is caused by environmental factors such as teachers, families and peers, guidance and psychological counseling services should be offered to these environmental factors.
\end{abstract}

Keywords: Guidance and psychological counseling, controlling mathematics anxiety, mathematics anxiety.

To cite this article: Aydın, D., \& Aytekin, C. (2019). Controlling Mathematics anxiety by the views of guidance and psychological counseling candidates. European Journal of Educational Research, 8(2), 421-431. doi: 10.12973/eu-jer.8.2.421

\section{Introduction}

Individuals are born with the natural ability to perform basic mathematical calculations in the case of no obstacles that would stagger them. Some of these skills are developed in appropriate environmental and personal conditions. Mathematics is an important subject not just for science and technology but also for daily life (Ilhan \& Oner-Sunkur, 2013). While mathematics is so important, high number of people stay away from mathematics, many of them do not feel to have self-confidence and self-inadequate in mathematics because of having high math anxiety (Demir \& Durmaz, 2018). Fear and anxiety from mathematics is seen to be a very common problem. Therefore, it can be asserted that most people did not have the appropriate environmental and personal conditions to develop their math skills. The fear of mathematics is defined as a feeling of tension, anxiety or fear of not being successful in mathematics (Ashcraft, 2002). Anxiety is classified into two groups. The first one is the situational anxiety that occurs under certain situations and conditions, the second is related to the personality of the individual (Arikan, 2004; Eldemir, 2006). Mathematics anxiety over a certain level might be uncontrollable by producing negative thoughts in students that may prevent learning mathematics. If math anxiety becomes a constant concern, it can cause individuals to fail to succeed in mathematics. Math anxiety can be dealt with by knowing and eliminating things that cause math anxiety. Studies have indicated that fearing mathematics is interrelated with negative thoughts towards the subject which lead to anxiety (Hembree, 1990). If a student with a certain level of mathematics ability is experiencing problems with the subject, this is probably due to their mathematics anxiety which has exceeded a certain level. According to Ashcraft (2002), students that suffer from high levels of anxiety cannot perform mathematical procedures that require intense attention and concentration.

It is possible to say that there is no consensus regarding the factors which induce mathematics anxiety (Richardson \& Suinn, 1972; Newstead, 1995). However, there is strong evidence about negative experiences found in the classroom causing students to generate anxiety (Tobias, 1978; Stodolsky, 1985). However, students' positive interactions with each other or group projects can be effective in reducing anxiety (Von Glasersfeld, 1991; Vacc, 1993). It has been observed that discussing different solution strategies in dealing with mathematics problems can have a significant impact on reducing mathematics anxiety (Greenwood, 1984).

\footnotetext{
* Corresponding author:

Davut Aydin, Department of Guidance and Psychological Counseling, Ahi Evran University, Turkey.

Email: drdavuta@gmail.com
} 
In the literature, the causes of math anxiety are grouped in three categories. These are situational reasons, personal reasons, and personality-related reasons. In the study conducted by Baloglu (2001), factors such as age, gender, and socioeconomic status are mentioned as personal reasons for anxiety. In the same study, talents, values, learning styles, attitudes, and self-confidence are mentioned as examples of personality-related reasons. In a study by Elmenek (2008) on how personality-related reasons increase math anxiety, the situation of individuals with learning disabilities was shown as an example. Elmenek (2008) found that individuals with learning disabilities self-confidence and anxiety levels increased. Baloglu (2001) defined the behaviors of teachers, family, and environment as situational reasons. Teachers' behaviors may increase the student's math anxiety if they put too much pressure on the student (Kececi, 2011). On the other hand, teachers that do not relate mathematics in to real life, it may increase math anxiety (Dede \& Dursun, 2008; Sirmaci, 2007; Baloglu, 2001). Durmaz (2012) stated that constructivist learning environments reduce students' math anxiety as they support the basic psychological needs of students. Similarly, Baltaci and Yildiz (2018) stated that the appropriate teaching for new approach types motivate students and increase their mathematics achievement. Ryan and Deci (2000a) identified three basic needs: competence, belonging, and autonomy. In their study, Ryan and Deci (2000a) stated that when the basic psychological needs of the students are not met, negative situations such as anxiety will increase and positive emotions will decrease in classroom environments. Durmaz and Akkus (2016) stated that students' mathematical anxiety could be reduced by supporting these needs in educational environments. Demir and Durmaz (2018) stated that situational math anxiety mostly stemmed from the wrong teaching style of teachers. In order to reduce this anxiety, it is clear that teachers need to provide education in a way that supports basic psychological needs in educational settings.

It is appropriate to begin with determining the exact level of anxiety in order to reduce it. Some scales have been developed to fulfil this purpose. For example, the first scale was developed by Richardson and Suinn (1972) satisfies this purpose. Ashcraft (2002) also found that those who lack confidence in succeeding in math tend to experience higher levels of anxiety. McLeod (1992) stated that the ages between 9 and 11 were the critical age range for developing emotional responses and attitudes towards mathematics. Although some apparent anxiety may appear during childhood, the negative attitudes found in the child's environment and family surroundings can contribute in heightening such anxieties. If the anxiety during childhood remains unchanged, it can cause serious problems later on in adulthood. In a study conducted by Hembree (1990), mathematics avoidance behaviour develops due to concerns developed from childhood. Skemp (1986) stated that childhood anxiety causes a decline in conceptual thinking and memory functions. This situation may cause mathematics anxiety in children, which leads to a decrease in their achievement (Hembree, 1990). Controllable anxiety is necessary to maintain performance but uncontrollable anxiety can adversely affect success. Wigfield and Meece (1988) stated that some anxiety may increase students' efforts in terms of achieving in mathematics. Thus, it can be alluded that mathematics' anxiety that can be controlled can also be positive. When moderate levels of anxiety are intertwined with the certain personality traits of an individual, this may lead to a positive impact on their performance. However, Skemp (1986) has stated that anxiety above a certain degree may adversely affect the academic performance and cognitive activities of an individual. Buxton (1981) investigated mathematics anxiety in children. Buxton (1981) affirmed that anxiety negatively affects the participation of children participation in mathematics lesson. Similarly, Richardson and Suinn (1972) have stated that anxiety had a negative effect on mathematics achievement in general.

Studies on how to reduce anxiety are vital in terms of reducing the affects that anxiety has on the children's academic performance. There is an insufficient number of experimental studies which examine the effect of different teaching methods and techniques on reducing mathematics anxiety. It is not possible to assert that using alternative teaching methods will reduce anxiety. Similarly, it is also not possible to assert that traditional teaching approaches will increase students' concerns. It is not just about only utilizing different teaching approaches which reduce mathematics anxiety, but how these approaches are applied to tackle this struggle. At this point, it can be said that the teacher has many responsibilities.

Most children from their pre-school period have a high sense of curiosity. Therefore, we can assume that children are naturally interested in mathematics in their everyday lives. However, it can be said that as they grow up, their anxiety increases due to their negative experiences and failures. Simsek (2010) found that one of the most favourite subjects of high school students was mathematics. However, the same research also revealed that mathematics was also the most difficult subject. Basar, Una, and Yalcin (2001) found that 87\% of the students had a fear and anxiety towards mathematics due to a number of different reasons. One of the most important factors that contribute to the fear and anxiety of mathematics is the actual teacher. Mathematics should be explained by taking into account the developmental periods of the students. For example, abstract concepts should be concretized to students in the period of concrete operations. Another reason is the imposition of the belief that students should be too smart to be successful in mathematics. If these situations are not resolved, students may develop mathematics anxiety. If the mathematics anxiety of children progresses, the belief that they will never succeed becomes stronger (Baykul, 2006).

Hannula (2002) defines attitude as the likes and dislikes of an individual in a particular situation. In other words, attitude is an individual's tendency to behave in a positive or negative way. Turgut and Baykul (2010) stated that negative attitudes prevented students' learning, whereas positive attitudes led them to be more interested in the 
lessons, to understand the importance of the subjects, and to be able to succeed. In fact, attitude affects success and success affects attitude (Aiken, 1970). Hannula (2002) stated that each class has its own social psychological climate, and this climate affects children's attitude towards mathematics.

Developing a positive attitude towards mathematics and providing self-confidence to students should be the common goal held by all mathematics teachers (Ministry of Education of Turkey, 2005). Thus, students' anxiety for math can be prevented, as well as their positive attitudes towards the subject increased. Some students have a negative attitude towards mathematics which decreases their self-confidence and leads them to believe that they are not smart nor capable in succeeding in mathematics (Baykul, 2006). Teachers should act based on the principle that every child is able to learn mathematics. Thus, teachers play a vital role in changing the attitude of children towards mathematics. By assisting students in coping and dealing with their mathematics anxiety, the success of students in mathematics can accordingly be increased.

Analyzing the studies on anxiety, it is generally seen that there are many studies about the cause of anxiety (Hembree, 1990; Arikan, 2004; Eldemir, 2006; Durmaz, 2012; Ashcraft, 2002; Richardson \& Suinn, 1972; Newstead, 1995; Tobias, 1978; Stodolsky, 1985; Ryan \& Deci, 2000; Kececi, 2011; McLeod, 1992) and reducing mathematics anxiety (Von Glasersfeld, 1991; Vacc, 1993; Greenwood, 1984; Durmaz, 2012; Demir \& Durmaz, 2018). However, there is no study examining the recommendations of psychological counseling and guidance candidates in dealing with math anxiety. Therefore, in this study, the question of "What are the suggestions of psychological counseling and guidance candidates in dealing with math anxiety?" is examined.

\section{Methods}

In this part of the study, a discussion on the research methods that are used to reveal the suggestions of GPCc candidates for reducing mathematics anxiety is presented. Information about the study participants and the implementation process are provided. Finally, the method of data collection and analysis are explained.

\section{Research Method}

The research was conducted using the special case study method. This study aimed to reveal the suggestions of the GPCc to deal with the mathematics anxiety found in young students. Therefore, an in depth examination of a certain group should be conducted. In addition, the data obtained from the study are interpreted according to the characteristics of the collected group and there is no generalization concern. For these reasons, the data of the study were evaluated in terms of the characteristics of the participants. Yildirim and Simsek (2008) stated that environment, individuals and processes are evaluated in special case studies without a concern for generalization.

\section{Participants}

The participants of the study consisted of third-grade students from the department of guidance and psychological counselling at a university in Turkey. Fifty GPC candidates participated in the study. Twelve of them were male and thirty-eight were female. The research was conducted at the end of the academic year. Within the scope of the study, the participants were asked about the kind of studies they would undertake in order to deal with their mathematics anxiety when they started the profession.

During the data collection phase of the study, GPC candidates completed most of the field's applied courses such as individual counselling, group counselling, vocational guidance, and counselling which are psychological counselling field's applied courses.

\section{Data Collection Tools}

Interviews were used to collect data for this study. The aim of the research was clearly explained to the participants before the interviews. Thus, the participants feel comfortable before the interview was initiated. They were also informed that the opinions they express will not be evaluated as a course grade. Necessary permissions was obtained from each of the participants before the interviews. Each interview took an average of 25 to 40 minutes. The interviews were held in the counselling room in the faculty which was a comfortable and quiet environment so that the participants feel comfortable.

\section{Data Analysis}

In data analysis, the coding method was used according to the concepts extracted from the study by Punch (2005) and Strauss and Corbin (1990). Since the data of the study were collected from interviews, the researchers transcribed the interviews in written text format. While the interviews were translated into written text, no corrections were made in the statements of the GPC candidate. Then, the data was read independently by the two researchers. In the first reading phase, the researchers aimed to present as many themes as they could. They then agreed to discuss these themes and provide them with similar theme names. After the researchers agreed on the themes, the data was read for a second time. In the second reading phase, they aimed to reveal the sub-themes for each of the main themes. The researchers standardized the sub-themes with their common decisions. They then identified the categories of each sub-theme and identified the expressions that fall into these categories. At this stage, a different code was used for each category. The 
researchers coded the data using these codes from the final reading. In the calculation of intercoder reliability, Miles and Huberman (1994)'s formula was used. The intercoder reliability coefficient between the encoders was 0.86 . The findings of the research are the results of the consensus of the researchers. The research findings were supported by direct expressions of the participants. Abbreviations such as (P1, P2, etc.) were used in the presentation of these statements. Abbreviations P1 represents participant one, P2 represents participant 2, etc.

\section{Findings}

The findings of the study were grouped under three main themes. The themes were named as "determining the current situation, direct, and indirect guidance services" to the client. The sub-themes' categories, frequencies, and percentages of each category are presented in tabular form.

Table 1. The Themes Related to Students' Coping with Mathematics Anxiety According to the Recommendations of GPC Candidates

\begin{tabular}{llcc}
\hline & Themes & f & \% \\
\hline 1 & Services of determining the current situation & 53 & 23.98 \\
2 & Direct guidance services & 126 & 57.01 \\
3 & Indirect guidance services & 42 & 19.00 \\
\hline & Total & 221 & 100 \\
\hline
\end{tabular}

When the themes related coping with mathematics anxiety according to the recommendations of GPC candidates are examined, it is seen that 53 of the 221 expressions are classified as services of determining the current situation, 126 of the 221 expressions are classified as direct guidance services, and 42 of the 221 expressions are indirect guidance services.

Table 2. The Results of Services for Determining the Current Situation

\begin{tabular}{|c|c|c|c|c|}
\hline Themes & Sub-Themes & Categories & $\mathbf{f}$ & $\%$ \\
\hline \multirow{10}{*}{$\begin{array}{l}\text { Services of } \\
\text { determining } \\
\text { the current } \\
\text { situation }\end{array}$} & \multirow{4}{*}{$\begin{array}{l}\text { Collecting } \\
\text { Information } \\
\text { for Life }\end{array}$} & I collect information about the clients' history of mathematics. & 2 & 3.7 \\
\hline & & I get information from the mathematics teacher on the child. & 2 & 3.7 \\
\hline & & I get information about when he/she is worried. & 3 & 5.6 \\
\hline & & $\begin{array}{l}\text { I try to empathize with the client to understand the basis of his } \\
\text { anxiety. }\end{array}$ & 2 & 3.7 \\
\hline & \multirow{2}{*}{$\begin{array}{l}\text { Collecting } \\
\text { information } \\
\text { about } \\
\text { Personality } \\
\text { Properties }\end{array}$} & I pay attention to individual differences. & 1 & 1.8 \\
\hline & & $\begin{array}{l}\text { I consider the age of the student, the level of the school and the } \\
\text { characteristics of the student. }\end{array}$ & 1 & 1.8 \\
\hline & \multirow{2}{*}{$\begin{array}{l}\text { Attitude } \\
\text { Information }\end{array}$} & \multirow{2}{*}{$\begin{array}{l}\text { I try to learn their thoughts (perception) about mathematics. } \\
\text { I look at the effects of my methods on attitudes of the client towards } \\
\text { anxiety. }\end{array}$} & 3 & 5.6 \\
\hline & & & 2 & 3.7 \\
\hline & $\begin{array}{l}\text { Reason } \\
\text { information }\end{array}$ & I try to uncover the real cause of anxiety of individual. & 32 & 60.3 \\
\hline & $\begin{array}{l}\text { Level } \\
\text { Determination }\end{array}$ & I determine the level of anxiety. & 5 & 9.4 \\
\hline Total & & & 53 & 100 \\
\hline
\end{tabular}

The results of the analysis are presented in Table 2 . When the statements of GPC candidates were examined, it was determined that 53 of the 221 statements $(23.98 \%)$ were related to the theme of the studies on the determination of the current situation. The sub-themes related to the status detection theme are as follows: The clients' past experience, personality traits, attitude, cause of anxiety, and anxiety level. It was observed that $32(60.3 \%)$ of the statements were related to the information gathering regarding the cause of anxiety. According to this result, it is seen that GPC candidates will work to reveal the cause of anxiety in order to cope with the anxiety situation of the individual. In addition, 5 of the statements (9.4\%) regarding the determination of the current status are aimed to determine the level of anxiety of the individual. GPC candidates stated that they will collect information about their experience (13\%), personality (3.6\%), and attitude (9.3\%) for the purposes of the case studies. 
Table 3. The Results of Direct Guidance Services

\begin{tabular}{|c|c|c|c|c|}
\hline Themes & Sub-Themes & Categories & f & $\%$ \\
\hline \multirow{24}{*}{$\begin{array}{l}\text { Direct } \\
\text { guidance } \\
\text { services }\end{array}$} & \multirow{5}{*}{$\begin{array}{l}\text { Awareness } \\
\text { Raising }\end{array}$} & I explain that mathematics exists in everyday life. & 4 & 3.1 \\
\hline & & I show him/her the benefits of reducing anxiety. & 4 & 3.1 \\
\hline & & I help him/her to realize his/her anxiety & 4 & 3.1 \\
\hline & & $\begin{array}{l}\text { I tell the lessons that he/she has been successful. I show them } \\
\text { what they did in these lessons. }\end{array}$ & 5 & 3.9 \\
\hline & & I will raise awareness. & 9 & 7.1 \\
\hline & \multirow{5}{*}{$\begin{array}{l}\text { Orientation } \\
\text { to Positive } \\
\text { Attitude }\end{array}$} & I organize seminars to encourage mathematics & 2 & 1.5 \\
\hline & & I try to set a goal according to age. & 4 & 3.1 \\
\hline & & I try to break his negative attitude towards mathematics. & 5 & 3.9 \\
\hline & & I work to increase motivation. & 5 & 3.9 \\
\hline & & I encourage the client. & 6 & 4.7 \\
\hline & \multirow{14}{*}{$\begin{array}{l}\text { Reducing } \\
\text { Anxiety }\end{array}$} & $\begin{array}{l}\text { I prepare a mathematics lesson plan with the student and follow } \\
\text { this plan. }\end{array}$ & 3 & 2.3 \\
\hline & & $\begin{array}{l}\text { I try him/her to be successful in mathematics with tasks that } \\
\text { increase from simple to difficult. }\end{array}$ & 4 & 3.1 \\
\hline & & I show those who deal with math anxiety as a role model. & 5 & 3.9 \\
\hline & & I try to make a positive use of anxiety. & 5 & 3.9 \\
\hline & & I try them to be dealing with their anxiety. & 4 & 3.1 \\
\hline & & I use educational guidance to reduce the level of anxiety. & 8 & 6.3 \\
\hline & & I try to find solutions with the student. & 1 & 0.7 \\
\hline & & I ty to reduce the negative effect of anxiety. & 10 & 7.9 \\
\hline & & $\begin{array}{l}\text { I try to make them like mathematics with age-appropriate } \\
\text { activities. }\end{array}$ & 4 & 3.1 \\
\hline & & I help them to eliminate her misconceptions. & 10 & 7.9 \\
\hline & & I help them to overcome desperation. & 4 & 3.1 \\
\hline & & I want the student to follow a path from simple to complex. & 4 & 3.1 \\
\hline & & I give the student homework and I want him to do. & 4 & 3.1 \\
\hline & & I use strategies to cope with anxiety & 12 & 9.5 \\
\hline Total & & & 126 & 100 \\
\hline
\end{tabular}

The results of the analysis regarding direct guidance service are given in Table 3 . The examination of the themes related to coping with mathematics anxiety based on the recommendation of GPC candidates indicates that 126 of the 221 expressions are classified as direct guidance services. The sub-themes related to the direct guidance services are; raising awareness $(20.3 \%)$, orientation to positive attitude (17.1\%), and reducing anxiety (62.2\%). In regard to the awareness raising sub-theme, 9 statements (7.1\%) fall in the category of awareness-raising. In terms of the sub-theme of positive attitude development, 6 statements (4.7\%) is observed to be in the category of encouraging the client. Regarding anxiety reduction sub-theme, it is seen that $10(7.9 \%)$ expressions fall into the category of reducing the negative effect of anxiety. It can be seen that $10(7.9 \%)$ of the expressions entered into the category of helping them to eliminate their misconceptions. It is also seen that $12(9.5 \%)$ expressions fall into the category of using strategies to cope with anxiety.

Table 4. The Results of Indirect Guidance Services

\begin{tabular}{|c|c|c|c|c|}
\hline Themes & Sub-Themes & Categories & f & $\%$ \\
\hline \multirow{9}{*}{$\begin{array}{l}\text { Indirect } \\
\text { guidance } \\
\text { services }\end{array}$} & \multirow{6}{*}{$\begin{array}{l}\text { Teacher } \\
\text { counselling }\end{array}$} & I work together with the mathematics teacher. & 13 & 30.9 \\
\hline & & I inform mathematics teacher. & 2 & 4.7 \\
\hline & & $\begin{array}{l}\text { I want from the mathematics teacher to do activities to increase } \\
\text { motivation. }\end{array}$ & 4 & 9.5 \\
\hline & & $\begin{array}{l}\text { I want from the mathematics teacher to reward students who answer the } \\
\text { question correctly. }\end{array}$ & 3 & 7.1 \\
\hline & & I want from the mathematics teacher to ask encouraging questions. & 2 & 4.7 \\
\hline & & I ask from mathematics teacher to be understanding & 1 & 2.3 \\
\hline & \multirow{2}{*}{$\begin{array}{l}\text { Family } \\
\text { counselling }\end{array}$} & I talk to his/her parents about his/her anxiety. & 10 & 23.8 \\
\hline & & I give an education to the family to reduce the anxiety level of children & 4 & 9.5 \\
\hline & $\begin{array}{l}\text { Peer } \\
\text { counselling }\end{array}$ & I can provide peer-assisted education. & 3 & 7.1 \\
\hline Total & & & 42 & 100 \\
\hline
\end{tabular}


The themes related to coping with mathematics anxiety based on the recommendations of GPC candidates indicates that 42 of the 221 expressions are indirect guidance services (Table 1). There are three sub-themes related to the theme of the guidance service indirectly given to the client. The first one is the guidance service for the teacher (59.6\%), the second for the guidance service for the family (33.3\%), and the third is for the peers (7.1\%). It is seen that 30.9\% of the expressions in the sub-theme of guidance services given to teacher are entered into the category of "I work together with the mathematics teachers." In the sub-theme "Family counselling", there is a category of "talking with the family about anxiety" (23.8\%). Besides, it is recommended to provide education for families (9.5\%).

\section{Discussion and Conclusion}

The findings of the study, in general, suggest to determine the experience, personality traits, attitudes, anxiety-causing factors, and anxiety levels before helping students to control their math anxiety. Because the reasons that cause anxiety in each individual may be situational or continuous and it may vary from individual to individual (Arikan, 2004; Eldemir, 2006). There is no consensus in the literature about what combined factors lead to math anxiety (Durmaz, 2012; Richardson \& Suinn, 1972; Newstead, 1995). The reason for the lack of consensus about the causes of anxiety in the literature is individual differences. Therefore, it may not be appropriate to treat each individual in the same way. Similarly, Tobias (1978) and Stodolsky (1985) stated that the main cause of mathematics anxiety is likely to be due to negative experiences that have occurred in the classroom. A similar statement was also expressed by Kececi (2011). Kececi (2011) said that negative behaviors of teachers increase students' concerns. A consultant who aims to reduce the individual's math anxiety should first determine whether this concern is due to negative experiences in the classroom or is caused by other factors. Thus, the effect of the help will increase. According to the research findings, studies that determine the level and source of mathematics anxiety have an important place in the guidance services. The most common expression was "gathering information for the cause" in this sub-theme. Students should be provided with the necessary guidance on math anxiety by revealing the real cause of anxiety. GPC candidates stated that in order to produce solutions, first of all, it is necessary to collect information about the "experience", "personality traits", "attitudes", "cause of anxiety", and "anxiety level" of the individual. A GPC candidate stated that "I raise awareness about the history of mathematics achievement. I create a graph showing the status of success and interest in mathematics from past to present" (GPC 12). Information about the situation of anxiety can be collected from the individual and his/her immediate environment. Other GPC candidate stated that "I empathize with them to understand the underlying cause of their anxiety. So I try to see them and their environment from their eyes" (GPC 5). Anxiety can be caused by an individual's personality traits and their individual differences. Another GPC candidate stated that "Everyone's intelligence level, perception and intelligence types are different. I also pay attention to the student's age, class level, and student characteristics" (GPC 7). McLeod (1992) stated that the ages of 9-11 years are important in determining the attitudes towards mathematics. It can be examined to see whether there are negative experiences in this age. Students' grade levels should be taken into consideration in students' mathematics anxiety assessment studies. Because, Fiore (2003) discovered a relationship among age, grade levels, and the anxiety levels of students. Similarly, Yenilmez and Ozabaci (2003) and Hannula (2002) found that students' attitudes towards mathematics decreased as their grades increased. This information can be taken into consideration in the determination of their current status.

One of the sub-themes of the "direct guidance service" is raising awareness. Increasing awareness is very important in reducing anxiety. A GPC candidate stated that "I learn the attitude of the student in other courses other than mathematics. Thus, I try to let the students to see the differences between his behaviors, attitudes, and thoughts in the classes he likes and dislikes. So I raise their awareness" (GPC 48). Following results were found in analyzing the sub-themes of the direct guidance service to deal with math anxiety. First, the awareness of the individual having math anxiety can be increased. In accordance with this finding, Durmaz (2012) stated that implementing the constructivist approach would reduce students' math anxiety. However, it may be useful to show the advantages of individuals who manage to cope with anxiety. The awareness of individuals who realize themselves will increase. If the individual's awareness of anxiety is increased, the avoidance behavior of mathematics expressed by Hembre (1990) can be prevented. Skemp (1986) stated that the decline in thinking and memory functions mostly stemmed from childhood concerns. Individuals who are aware of their anxiety can produce their own internal solutions for "not affecting thinking and memory functions" or they can adapt more easily to the consultation process. Hembree (1990) affirmed that mathematics anxiety can lead to a decrease in student achievement. If those that suffer from mathematics anxiety are able to see that they will succeed more if they controll their anxiety, then they will have a stronger will to deal with it effectively. In the literature, it was found that uncontrollable anxiety was negatively affecting academic performance (Skemp, 1986). However, Wigfield, and Meece (1988) stated that controllable anxiety may increase the effort for mathematics achievement. As suggested by the GPC candidates, it is possible to realize that the individual can use their anxiety as a motive to succeed in controlling his anxiety and accordingly enhance their mathematics performance.

Moreover, GPC21 stated that "I try to raise their awareness about that the events will be easier if they control their anxieties. Thus, their perspective on mathematics may change." This proposal of the PDR candidate should be taken into consideration by the consultants and teachers. Buxton (1981) stated that mathematics anxiety had a negative effect on students' achievement because it prevents students from attending the lessons. In this case, as GPC45 says, the suggestion that "I can help students to connect mathematics not only with school but with life" may be useful. Students 
who see that mathematics already exists in life may increase their participation in class. Thus, these students were able to manage and control their anxiety. If students are able to manage and control their concerns, they will be able to succeed by participating more in class activities which will become easier over time.

The second result that can be drawn from the findings related to the direct guidance service to deal with the anxiety of mathematics is to guide students to have a positive attitude towards mathematics. Findings of this study indicated that if students have a positive attitude towards mathematics, they can manage to deal with math anxiety. GPC candidates suggested organizing the seminars to encourage students to be successful in mathematics, set goals appropriate for age, cope with negative attitudes, and motivate and encourage the students. Studies show that the fear of mathematics is mostly associated with negative attitudes caused by mathematics anxiety (Hembree, 1990). Attitude was defined by Hannula (2002) as whether the individual likes a situation. If an individual that suffers from mathematics anxiety, it indicates that he/she does not like mathematics. Therefore, it may be useful to try and transform their negative attitudes to positive ones. Because, negative attitudes prevent students to learn effectively.

One GPC candidate stated that "If the student has an inherent motivation problem, I deal with his ability to motivate himself. I try to find fun mathematics activities for the student to like mathematics. So I can help him reduce his anxiety. In short, I try to raise awareness that it is not impossible to succeed in mathematics. I tell the student that every student can do the mathematics. Individual differences will facilitate or make it difficult" (GPC41). On the other hand, positive attitudes make them interested in the lesson and understand the importance of subjects (Turgut \& Baykul, 2010). In the literature, it has been stated that the attitude affects the success and the success affects the attitude (Aiken, 1970). For this purpose, it is important to encourage and motivate students to succeed. As a matter of fact, it is among the general objectives of mathematics teaching that students gain a positive attitude and increase self-confidence in mathematics (Ministry of Education of Turkey, 2005). If students are not encouraged, they may experience negative attitudes. As a result, they may suffer from lack of self-confidence by experiencing negative thoughts that make them believe they are not smart enough to perform well in mathematics (Baykul, 2006).

The current study concluded that, if necessary, psychological counselors should help students to avoid their unrealistic believes or eliminate their learned helplessness in order to reduce their math anxiety. Because, some students' mathematics anxiety can be caused by unrealistic believes about not being able to do mathematics. A GPC candidate stated that "Students may experience anxiety mostly because of irrational thoughts. I try to help him deal with those thoughts" (GPC40). Individuals may have suffered from negative experiences with mathematics in the past. Therefore, the individual may have learned helplessness. Another GPC candidate stated that "If the student experiences a learned despair of mathematics, I try to change them with rational thoughts. I will focus on this topic in the counselling service that I will give to the student. In addition, giving homework can be useful" (GPC 46). Similar cases have been mentioned in the literature. In order to overcome this anxiety, GPC candidates suggest a learning path from simple to complex. It is possible for the student to succeed in mathematics to experience the gradually increasing successes. Another GPC candidate stated that "If there are times when the student is a little successful in mathematics, I remind them. So I show him that he can actually succeed in mathematics" (GPC24). Another PDR candidate stated that "If the student has a prejudice against mathematics, he can have anxiety. Therefore, it is necessary to show that he can do mathematics starting from the questions he can do easily. If they do this, their anxiety may decrease over time. In my opinion, methods should be applied to change the student's perspective on mathematics" (GPC27). GPC candidates may be useful for students who experience high anxiety to try to make them love mathematics through activities that are appropriate for their age. It is recommended by GPC candidates that students with a high level of anxiety, it may be useful to try to love mathematics with activities appropriate for their age. In addition, individuals who beat mathematics anxiety can be shown as role models. In support of these findings, Aiken (1970) stated that positive attitudes increased their success by decreasing student anxiety. It is recommended by GPC candidates that providing educational guidance and dealing with anxious coping strategies. Educational guidance is a service given to the whole class. Hannula (2002) emphasized that each class has a specific social-psychological climate and this climate affects children's attitudes towards mathematics. If this climate is directed towards a more positive approach, negative mathematics anxiety can then be reduced. Von Glasersfeld (1991) and Vacc (1993) stated that positive interactions among students are effective in reducing anxiety.

Controllable anxiety is known to increase student performance. In this regard, some of the GPC candidates have suggested to make use of their anxiety in a more positive way. Some participants stated that activities such as preparing a mathematics lesson plan, giving homework and follow-up could reduce the anxiety of students. Greenwood (1984) stated that speaking to the student regarding different solutions to overcome anxiety can improve the facilitation of coping with anxiety related to mathematics.

Findings of this study suggest that it may be useful to provide counseling services to the teacher, family, and peers if the student's math anxiety arises from environmental factors. If math anxiety arises from the teacher, it may be useful to collaborate with the teacher. Kececi (2011) stated that negative teacher behaviors increase students' math anxiety. If teachers show mathematics to pupils in relation to everyday life, they can reduce math anxiety (Dede ve Dursun, 2008; Sirmaci, 2007; Baloglu, 2001). Durmaz (2012) further stated that teachers who act in accordance with the constructivist approach can be effective in reducing students' math anxiety. The findings of this study also suggest to work in cooperation with the mathematics teacher in order to increase the motivation of the students and encourage 
them. The counceling services for teachers include cooperation with the mathematics teachers, informing the mathematics teachers, increasing the motivation of the students, and encouraging them. A GPC candidate stated that "Sometimes there may be an anxiety caused by external factors in students. These factors can be family, environment and classroom environment. I inform to the mathematics teacher about the differentiation of materials, activities and learning and teaching methods. These are useful for the student to approach mathematics more positively" (GPC 41). Buxton (1981) stated that mathematics anxiety prevents students from attending the class. If indirect guidance is provided to the teachers, teachers may apply different methods to include anxious students in classroom activities.

The current study also concludes that providing guidance to the family in order to reduce the math anxiety of the students may be useful. Because some families may cause math anxiety for their kids due to their wrong attitudes and behaviors. The literature mentions that the negative behaviors of the family may cause math anxiety. For example, Baloglu (2001) listed the negative behaviors of the family among the situational reasons that constitute math anxiety. The influence of the family on the attitude and achievement towards mathematics attracted the attention of many researchers (Uysal, 2007; Yetim, 2006; Varol, 1990; Gumus, 1997; Yetim, 2006; Yenilmez \& Ozabaci, 2003; Akdemir, 2006; Yilmaz, 2006; Aytekin, Baltaci \& Yildiz, 2018; Aytekin, Baltaci, Altunkaya, Kiymaz \& Yildiz, 2016). A GPC candidate stated that "I conduct consultancy services with his / her family to overcome mathematics anxiety" (GPC32). In these interviews and trainings, we can focus on what can be done to increase the motivation of the students and encourage them. If the education level of the family is low and the economic level is insufficient, it may decrease the motivation of the students and increase their anxiety (Yenilmez \& Ozabaci, 2003). In some studies, it was found that children's anxieties were high, and at the same time their motivations were low, as they could not meet the needs of their children (Alisinanoglu \& Ulutas, 2000; Varol, 1990; Aral, 1997; Girgin, 1990). It is important to increase the motivation and self-confidence of the students to control their anxiety. The level of anxiety was found to be high among students who achieved lower levels of success at school (Bozak, 1982; Sargin, 1990; Aral, 1997; Varol, 1990; Spielberger, 1979).

Another finding of this study showed that if the individual's anxiety with mathematics arises from his peers, it may be helpful to provide peer-assisted guidance. Hannula (2002) stated that each class has a social psychological climate and this climate affects children's attitude towards mathematics. It is seen that the category of providing peer-aided education is in the sub-theme of consultancy services for peers. A GPC candidate stated that "The cause of anxiety in the students can be family, lack of self-efficacy, teachers or friends. If it was caused by friends, It would be useful to provide peer-assisted education" (GPC7). Providing peer-aided education from indirect guidance services can lead to a positive climate, even if it is not directly effective to the counselor. Similarly, the literature strongly emphasize that peerassisted instruction is very important for students' mathematics achievement (Olpak, Baltaci \& Arican, 2018; Olpak, Arican \& Baltaci, 2018).

\section{Suggestions}

According to the results of this study, following suggestions can be made for students to control their math anxiety.

- The reasons for math anxiety vary individually. Therefore, individual recognition techniques (test and non-test) should be used effectively to help students control their anxiety.

- Before starting to help, information should be collected about the individual's life, personality traits, attitudes, anxiety level, and causes of anxiety.

- In order to control anxiety in students, psychological counseling techniques should be used in order to raise awareness about anxiety.

- Appropriate counseling techniques can be applied to students that have negative attitudes towards mathematics.

- To reduce anxiety, guidance and psychological counseling should be conducted in order to cope with misconceptions, unrealistic thoughts, and learned helplessness.

- If math anxiety arises from the teacher, family, and peers, guidance and counseling should be provided for these groups.

\section{References}

Aiken, L. R. (1970). Attitudes toward mathematics. Review of Educational Research, 40(4), 551-596.

Akdemir, 0. (2006). Ilkogretim ogrencilerinin matematik dersine yonelik tutumlari ve basari gudusu [Elementary students' attitudes towards mathematics lesson and achievement motivation] (Unpublished Master's Thesis). Dokuz Eylul university, Izmir, Turkey.

Alisinanoglu, F., \& Ulutas, I. (2000). Cocuklarda kaygi ve bunu etkileyen etmenler [Childhood anxiety and affecting factors] (p.145). Ankara: Milli Egitim Egitim Sanat Kultur Yayinlari.

Aral, N. (1997). Fiziksel istismar ve cocuk [Physical abuse and child]. Ankara: Tekisik Ofset Tesisleri. 
Arikan, G. (2004). Ogrencilerin matematik kaygi duzeyleri ile matematik basari duzeyleri arasindaki iliski ilkogretim 2. Kademe [The relationship between the students' maths anxiety levels and maths achievements levels] (Unpublished master's thesis). Gazi University, Ankara, Turkey.

Ashcraft, M. H. (2002). Math anxiety: Personal, educational, and cognitive consequences, current directions. $J$ Psychological Science, 11(5), 181-185.

Aytekin, C., Baltaci, S., Altunkaya, B., Kiymaz, C., \& Yildiz, A. (2016). Matematik Egitimi Veli Beklenti Olcegi'nin Gelistirilmesi (MEVBO): Gecerlik ve Guvenirlik Calismasi [A Scale to Determine Parents' Expectation from Mathematics Education (PEME): Development, Reliability and Validity]. Ahi Evran Universitesi Kirsehir Egitim Fakultesi Dergisi (KEFAD), 17(3), 397-411.

Aytekin, C., Baltaci, S., \& Yildiz, A. (2018). Investigation of parents' expectations from mathematics education in Turkey. Acta Didactica Napocensia, 11(3-4), 59-78. doi: 10.24193/adn.11.3-4.5.

Baloglu, M. (2001). Defeat the fear of mathematics. Educational Sciences: Theory \& Practice, 1(1), 59-76.

Basar, M., Una, M., \& Yalcin, M. (2011, Spetember). Ilkogretim kademesiyle baslayan matematik korkusunun nedenleri [Causes of math fear starting with primary education]. Paper presented at the V. Ulusal Fen Bilimleri ve Matematik Egitimi Kongresi, ODTU, Ankara.

Baykul, Y. (2006). Ilkogretimde matematik ogretimi (1.-5. siniflar) [Teaching mathematics in primary education (grades 1-5)]. Ankara, Turkey: Pegem.

Bozak, M. M. (1982). Anksiyete ve okul basarisi arasindaki iliskiye ait bir arastirma [A study of the relationship between anxiety and school success]. Psikoloji Dergisi, 16, 24-39.

Buxton, L. (1981). Do you panic about mathematics? London, UK: Heinemann Educational Books.

Dede, Y., \& Dursun, S. (2008). Ilkogretim II. kademe ogrencilerinin matematik kaygi duzeylerinin incelenmesi [An investigation of Primary School Students' Mathematics Anxiety Levels]. Journal of Uludag University Faculty of Education, 21(2), 295-312.

Demir, S., \& Durmaz, M. (2018). Ilkogretim Matematik Ogretmenlerinin Matematik Kaygisi Hakkindaki Gorusleri ve Mudahale Yontemleri [A opinions of elementary maths teachers about maths anxiety and their intervention methods]. Academia Journal of Eucational Research, 3(1), 17-27.

Durmaz, M., \& Akkus, R. (2016). Mathematics anxiety, motivation and the basic psychological needs from the perspective of self-determination theory. Education and Science, 41(183), 111-127. doi: 10.15390/EB.2016.2942

Durmaz, M. (2012). Ortaogretim ogrencilerinin (10.Sinif) temel psikolojik ihtiyaclarinin karsilanmislik duzeyleri, motivasyon ve matematik kaygisi arasindaki iliskilerin belirlenmesi [Identifying the relationships among the degrees of basic pyschological needs satisfaction, motivation and mathematics anxiety of high school students] (10th grade) (Unpublished master's thesis). Abant Izzet Baysal University, Bolu, Turkey.

Eldemir, H. H. (2006). Sinif ogretmeni adaylarinin matematik kaygisinin bazi psiko-sosyal degiskenler acisindan incelenmesi (Cumhuriyet universitesi ornegi) [Examining of preservice primary teachers'mathematics anxiety in relation to some psycho-social variables] (Unpublished master's thesis). Cumhuriyet University, Sivas, Turkey.

Elemek, M. A. (2008). Ogrenme bozuklugu olan cocuklarda benlik saygisinin ve kaygi durumunun incelenmesi [A study about self-respect and anxiety level with learning disorder] (Unpublished master's thesis). Marmara University, Istanbul, Turkey.

Fiore, A. M. (2003). Gender differences in test anxiety (Unpublisherd master thesis). The College of Human Resources and Education, West Virginia University, West Virginia, USA.

Girgin, G. (1990). Farkli sosyo ekonomik kesimden 13-15 yas grubu ogrencilerde kaygi alanlari ve kaygi duzeylerinin basariyla iliskisi [The relationship between anxiety levels and anxiety areas with academic achievement in 13-15 age group students from different socio-economic backgrounds] (Unpublished master's thesis). Dokuz Eylul University, Izmir, Turkey.

Greenwood, J. (1984). My anxieties about math anxiety. Mathematics Teacher, 77(9), 662-663.

Gumus, A. (1997). Universite ogrencilerinin sosyal kaygi duzeylerinin cesitli degiskenlere gore incelenmesi [Examination of social anxiety levels of university students according to various variables] (Unpublished master's thesis). Gazi University, Ankara, Turkey.

Hannula, M. S. (2002). Attitude towards mathematics: Emotions, expectations and values. Educational Studies in Mathematics, 49(1), 25-46. doi: 10.1023/A:1016048823497 
Hembree, R. (1990). The nature, effects, and relief of mathematics anxiety. Journal for Research in Mathematics Education, 21(1), 33-46. doi: 10.2307/749455

Ilhan, M., \& Oner-Sunkur, M. (2013). Matematik kaygisinin matematik basarisini yordama gucunun cinsiyet ve sinif degiskeni acisindan incelenmesi [Investigation of Predictive Power of Mathematics Anxiety on Mathematics Achievement in Terms of Gender and Class Variables]. Gaziantep University Journal of Social Sciences, 12(3), 427441.

Kececi, T. (2011, April). Matematik kaygisi ve korkusu ile mucadele yollari [Methods of combating math anxiety and fear]. Paper presented at the 2nd International Conference on New Trends in Education and Their Implications, Antalya, Turkey.

McLeod, D. B. (1992). Research on affect in mathematics education: A reconceptualisation. In D. A. Grouws (Ed.), Handbook of Research on Mathematics Teaching and Learning (575-596). Reston, VA: The National Council of Teachers of Mathematics.

Miles, M. B., \& Huberman, A. M. (1994). Qualitative data analysis: An expanded sourcebook. Thousand Oaks, CA: Sage.

Ministry of Education of Turkey (2005). Ilkogretim matematik 6-8 sinif ogretim programi [Elementary Mathematics Curriculum for 6-8 Grade]. Ankara: MEB.

Newstead, K. (1998). Aspects of childrens' mathematics anxiety. Educational Studies in Mathematics, 36(1), 53-71.

Olpak, Y. Z., Arican, M., \& Baltaci, S. (2018). Ogretmen adaylarinin ogrenme yaklasimlarinin ve bireysel yenilikcilik ozelliklerinin akran ogretimine yonelik memnuniyetlerine etkisi [The effects of preservice teachers' learning approaches and individual innovativeness characteristics on their satisfaction towards peer instruction]. Yuzuncu Yil Universitesi Egitim Fakultesi Dergisi [Van Yuzuncu Yil University Journal of Education], 15(1), 525-551. doi: 10.23891/efdyyu.2018.78

Olpak, Y. Z., Baltaci, S., \& Arican, M. (2018). Investigation the effects of peer instruction on preservice mathematics teachers' achievements in statistics probability. Education and Information Technologies, 23(6), 23232340. doi:10.1007/s10639-018-9717-3

Punch, K. F. (2005). Introduction to social research: Quantitative and qualitative approaches (2nd ed.). London, UK: Sage Publications.

Richardson, F. C., \& Suinn, R. M. (1972).The mathematics anxiety rating scale: Psychometric data. Journal of Counseling Psychology, 19(6), 551-554. doi: 10.1037/h0033456

Ryan, R. M., \& Deci, E. L. (2000). The darker and brighter sides of human existence: Basic psychological needs as a unifying concept. Psychological Inquiry, 11(4), 319-338. doi: 10.1207/S15327965PLI1104_03

Sargin, N. (1990). Lise I. ve III. sinif ogrencilerinin durumluk-surekli kaygi duzeylerinin belirlenip karsilastirilmasi [Determining and comparing the state-trait anxiety levels of high school 1st grade and third grade students] (Unpublished master's thesis). Dokuz Eylul University, Izmir, Turkey.

Simsek, H. (2010). Guneydogu anadolu bolgesindeki lise ogrencilerinin sosyal butunlesme duzeyleri ve gelecek beklentileri 0 [Social integration levels and future expectations of high school students in Southeast Anatolia region]. 109K300 Nolu Proje Sonuc Raporu [Project Result Report No. 109K300]. Ankara, Turkey: TUBITAK.

Sirmaci, N. (2007). A Study on the investigation of the university students' anxiety and attitudes toward mathematics: Erzurum Sample. Education and Science, 145(35). 53-70.

Skemp, R. R. (1986). The psychology of learning mathematics. Harmondsworth, UK: Penguin.

Spielberger, C. D. (1979). Understanding stress and anxiety. New York, NY: Harper \& Row.

Stodolsky, S. S. (1985). Telling math: Origins of math aversion and anxiety. Educational Psychologist, 20(3), $125-133$.

Tasdemir, C. (2008). Ilkogretim 6., 7. ve 8. sinif ogrencilerinin matematik dersine yonelik tutumlarinin bazi degiskenlere gore belirlenmesi: Bitlis ili ornegi [Detection of the elementary educatlon 6, 7 and 8 level students' attitudes to the mathematic lesson in according to the some variables: an example for Bitlis city]. Journal of Kazım Karabekir Education Faculty, 17, 184-201.

Tobias, S. (1978). Overcoming math anxiety. New York, NY: Norton.

Turgut, F. M., \& Baykul, Y. (2010). Egitimde olcme ve degerlendirme [Measurement and evaluation in education]. Ankara, Turkey: Pegem Akademi.

Uysal, O. (2007) Ilkogretim II. kademe ogrencilerinin matematik dersine yonelik problem cozme becerileri, kaygilari ve tutumlari arasindaki iliskilerin degerlendirilmesi [Evaluation of Relation between Problem Solving Skills, Anxiety 
and Attitudes of Secondary Education Grade II Students directed towards Mathematics Course] (Unpublished master's thesis). Dokuz Eylul University, Izmir, Turkey.

Vacc, N. N. (1993). Teaching and learning mathematics through classroom discussion. Arithmetic Teacher, 41(4), 225227.

Varol, S. (1990). Lise son sinif ogrencilerinin kaygilarini etkileyen etmenler [Factors affecting the concerns of senior high school students] (Unpublished master's thesis). Ondokuz Mayis University, Samsun, Turkey.

Von Glasersfeld, E. (Ed.) (1991). Radical constructivism in mathematics education. New York, NY: Kluwer Academic Publishers

Wigfield, A., \& Meece, J.L., (1988). Math anxiety in elementary and secondary school students. Journal of Educational Psychology, 80(2), 210-216.

Yenilmez, K., \& Ozabaci, N. (2003). Yatili ogretmen okulu ogrencilerinin matematik ile ilgili tutumlari ve matematik kaygi duzeyleri arasindaki iliski uzerine bir arastirma [The relationship between mathematics attitudes and mathematics anxiety of teacher high school students]. Pamukkale University Journal of Education, 2(14), 132-146.

Yetim, H. (2006). Ilkogretim 8. sinif ogrencilerinin matematik ve turkce derslerine yonelik tutumlari ile bu derslerdeki basarilari arasindaki iliski [The relationship between 8th grade primary school students' attitudes towards mathematics and Turkish courses and their achievement in these courses] (Unpublished doctoral thesis). Dokuz Eylul University, Izmir, Turkey.

Yildirim, A., \& H. Simsek, (2006). Sosyal bilimlerde nitel arastirma teknikleri [Qualitative research techniques in social sciences]. Ankara, Turkey: Seckin.

Yildiz, A., \& Baltaci, S. (2018). Iki farkli kurumda calisan ortaokul matematik ogretmenlerinin yaraticiligi destekleme durumlarinin incelenmesi [An analysis of the creativity fostering behaviors of secondary school mathematics teachers working at two different institutions]. Yuzuncu Yil Universitesi Egitim Fakultesi Dergisi [Van Yuzuncu Yil University Journal of Education], 15(1), 1392-1418. doi: 10.23891/efdyyu.2018.109

Yilmaz, M. (2006). Ilkogretim 6.sinif ogrencilerinin matematik dersine iliskin tutumlarinin bazi degiskenlere gore incelenmesi [Examining the attitudes of the 6th grade students in the mathematics course according to some variables]. Milli Egitim Dergisi [Journal of National Educational], 35(172), 240-249. 